\title{
Endangered and endemic species increase forest conservation values of species diversity based on the Shannon-Wiener index
}

\author{
Qingfeng Song, Bing Wang, \\ Jinsong Wang, Xiang Niu
}

\begin{abstract}
Species diversity is the most important component of biodiversity and plays an important role in maintaining forest ecosystem processes and stability. The assessment of the forest conservation value of species diversity is commonly carried out based on the Shannon-Wiener index. However, endangered and endemic species were always ignored in previous studies aimed at assessing the conservation value of forest species diversity. In this study, the conservation value of forest species diversity was assessed in two representative provinces of southern and northern China (Yunnan and Jilin provinces, respectively). The conservation values of species diversity for different forest types was calculated based on the standard Shannon-Wiener index, and on two different indexes derived from it by including: (i) an endangered species index $\left(E_{i}\right)$ based on the China Species Red List; (ii) an endemic species index $\left(B_{x}\right)$ based on the geographic distribution of the species considered. The results showed that the inclusion of the endangered and endemic species indexes dramatically increased the forest conservation values in these two provinces. The total conservation value in the Yunnan province was 268.65 billion yuan $\mathrm{yr}^{-1}$ based on the Shannon-Wiener index, 269.78 billion yuan $\mathrm{yr}^{-1}$ after including $E_{\mathrm{i}}$ in the assessment, and 324.44 billion yuan $\mathrm{yr}^{-1}$ after the inclusion of both $E_{\mathrm{i}}$ and $B_{\mathrm{x}}$. In Jilin province, the total conservation value was 123.94 billion yuan $\mathrm{yr}^{-1}$ based on the standard Shannon-Wiener index, 124.60 billion yuan $\mathrm{yr}^{-1}$ after including $E_{\mathrm{i}}$, and 125.74 billion yuan $\mathrm{yr}^{-1}$ after including both $E_{\mathrm{i}}$ and $B_{\mathrm{x}}$ in the assessment. Therefore, the inclusion of endangered and endemic species in the assessment of forest conservation values, as well as other aspects related to biodiversity like the presence of ancient trees, can contribute to the protection of endangered and endemic species in these two provinces of China.
\end{abstract}

Keywords: Species Diversity, Conservation Value, Endangered Species, Endemic Species

Species diversity, the most important level of biodiversity (Pimentel et al. 1997), is a measure of the number of species in a particular region (Nunes \& Van Den Bergh 2001). Species diversity is fundamental as it enhances ecosystem productivity and stability (Odum 1950) and affects ecosystem structure and function (Cardinale et al. 2006).

Forest biodiversity conservation is aimed at promoting the survival of different species in forest ecosystems (Li 2007, Cushman et al. 2008). Bollmann et al. (2009) three different level ving gene, species, and ecosystem diversity (United Nations 1993, Mooney 2009).

\section{$\square$ Research Institute of Forest Ecology and Environmental Protection, Chinese Academy of Forestry, Beijing 100091 (China)}

@ Bing Wang (wangbingcfern@163.com)

Received: Jun 09, 2014 - Accepted: Aug 18, 2015

Citation: Song Q, Wang B, Wang J, Niu X (2015). Endangered and endemic species increase forest conservation values of species diversity based on the Shannon-Wiener index. iForest 9: 469-474. - doi: 10.3832/ifor1373-008 [online 2016-01-02]

Communicated by: Chris Eastaugh argued that near-natural sustainable management and the protection of habitats for rare and endangered species in forest ecosystems should be the main targets of forest biodiversity conservation. Furthermore, forest biodiversity is one of the main forest ecosystem services (Naeem et al. 1994, Tilman et al. 1996, Terborgh 1998, Niu et al. 2012). However, our understanding of how to quantify forest biodiversity is still not fully clear (Simberloff 1999, Kuuluvainen 2002).

The assessment of biodiversity includes use and non-use values. The former consists of direct and indirect value, while the latter comprises existence and option values (Kellert 1997, Song 2004). The conservation value of species diversity is a part of non-use value, and is primarily related to the provision of species and genetic resources for ecosystem succession and biological evolution, which play an important role in maintaining ecosystem processes and stability (Schwartz et al. 2000). The ability to assess the conservation value of species diversity is a premise of effective biodiversity protection and sustainable utilization. 
It is widely reported that methods for evaluating the conservation value of species diversity include the actual market price, as well as simulated market, alternative market, contingent valuation (CV), willingness to pay (WTP), expense payment, and cost-benefit methods (OECD 1996, Van Jaarsveld et al. 1998, Jakobsson \& Dragun 2001, Christie et al. 2006). However, the common shortcomings of current methods are that they do not reflect the functional value of species in the ecosystems, but are predominantly affected by human-oriented criteria. Thus, these evaluation methods cannot correctly reflect the actual conservation value of species diversity.

Since the 1950, twenty-seven different indexes have been used to assess species diversity (Yue et al. 1998a, 1998b). The most widely used is the Shannon-Wiener index, that can reflect species richness and species evenness. According to the forestry industry standard of the People's Republic of China "Specifications for Assessment of Forest Ecosystem Services in China (LY/T 1721-2008)" issued by the State Forestry Administration (PRC Forestry Industry Standard 2008), we previously assessed for the first time the conservation values of Chinese forest ecosystems using the Shannon-Wiener index (Wang et al. 2008, Niu et al. 2013). Subsequently, this index was applied to evaluate the conservation values of different forest ecosystems in China (Wang \& Lu 2009, Wang et al. 2011a, 2011b).

For assessing forest ecosystem services, the above forestry industry standard requires the use of specific data sources, the evaluation of several system processes and the application of a given formula that combines all the information in a synthetic index. Three different sources of data are considered: (i) long-term observation data form CFERN; (ii) forest resources inventory data from the State Forestry Administration; and (iii) social/public resource data published by the authority. The eight system processes evaluated are: (i) water conservation; (ii) soil conservation; (iii) carbon fixation; (iv) oxygen release; (v) nutrient accumulation by plants; (vi) biodiversity conservation; (vii) the protective efficiency of forests; and (viii) forest recreation. Finally, the formula accounted for both the quantity and quality of each of the above

Tab. 1 - Different levels of the ShannonWiener index and the corresponding monetary value.

\begin{tabular}{ccc}
\hline $\bar{\Xi}$ & $\begin{array}{l}\text { Shannon-Wiener } \\
\text { index }\end{array}$ & $\begin{array}{c}\text { Monetary value } \\
\text { (yuan } \mathrm{hm}^{-2} \mathrm{yr}^{-1} \text { ) }\end{array}$ \\
\hline 1 & Index $\geq 6$ & 50000 \\
2 & $5 \leq$ Index $<6$ & 40000 \\
3 & $4 \leq$ Index $<5$ & 30000 \\
4 & $3 \leq$ Index $<4$ & 20000 \\
5 & $2 \leq$ Index $<3$ & 10000 \\
6 & $1 \leq$ Index $<2$ & 5000 \\
7 & Index $<1$ & 3000 \\
\hline
\end{tabular}

processes and data sources. Though suitable for assessing forest ecosystem services in China, the standard described above does not include other important aspects, such as the use of forest resources, forest by-products, or intrinsic forest value.

Although the Shannon-Wiener index is recognized as a classic indicator of species diversity, the important role of endangered and endemic species is always ignored in the assessment of the conservation value of forest species diversity. Indeed, two forest stands may show the same ShannonWiener index values regardless of the presence of endangered or endemic species in one of them. This calls for the inclusion of new criteria related with endangered and endemic species in the calculation of species diversity using the Shannon-Wiener index.

Endangered species are important components of forest ecosystems. Nonetheless, the rapid growth of the human population, the destruction of natural habitats, the over-exploitation of natural resources, environmental pollution, and the introduction of exotic species have threatened a large number of species with extinction (Norris 2012). Generally, endangered species always have a disproportionate conservation value than that of common species, leading to enhanced conservation efforts (Cheng \& Zang 2004).

Endangered categories are an important tool used to determine the conservation value of species, as well as the development of conservation strategies and priorities for endangered species. By signing the "Convention on Biological Diversity", some countries and international organizations recognized the assessment of species' endangered statuses as an important step in biodiversity conservation work. In the 1990s, China published the "China Plant Red Data Book" and "China Red Data Book of Endangered Animals" (Fu 1991, Wang 1998).

The heterogeneity of natural habitats, plant genetic variability, as well as interspecific hybridization, may result in endemic species (Sodhi et al. 2004), which in many cases represent unique indicators of some vegetation types (Vilenkin et al. 2009). Being highly dependent upon their specific habitats, endemic species may become endangered as a consequence of habitat destruction or depletion. Therefore, degradation of regions harboring a great number of endemic species would entail a remarkable loss of biodiversity (Brooks et al. 2006).

Bonn et al. (2002) considered that threatened and endemic species are good indicators of patterns of biodiversity on a regional scale. Dobson et al. (1997) used a database of threatened and endangered species in the United States to examine patterns in the geographic distribution of imperiled species. Ceballos et al. (1998) reported that areas of high species richness (i.e., regions with high numbers of endan- gered and endemic species) should be recognized as conservation priority areas. As the special conservation values of endangered and endemic species have become appreciated, more attention should be paid to such species when assessing forest biodiversity conservation values.

In this study, we assessed the conservation values of forest species diversity in Yunnan and Jilin provinces, which are representative provinces of southern and northern China, respectively. The conservation values were calculated based on the Shannon-Wiener index, and a specific endangered species index and an endemic species index were added to amend the calculation in a stepwise manner. These three assessment methods were tested and verified to select the best one.

\section{Materials and methods}

\section{Assessing conservation value based on} the Shannon-Wiener index

The conservation values of different types of forest stands in Yunnan and Jilin provinces were calculated based on the Shannon-Wiener index, defined as follows (eqn. 1):

$$
H^{\prime}=-\sum_{i=1}^{s} p_{i} \log p_{i}
$$

where $p_{\mathrm{i}}$ is the proportion of individuals belonging to the $i$-th species in the total population. Index values calculated for each stand type were then divided into seven levels (see Tab. 1), and for each level the conservation value of species diversity per unit area was assigned based on the Forestry Industry Standard of the People's Republic of China "Specifications for Assessment of Forest Ecosystem Services in China (LY/T 1721-2008)" (Tab. 1 - PRC Forestry Industry Standard 2008).

The total conservation value of species diversity was calculated for all stands by multiplying the stand area and the conservation value of species diversity per unit area (eqn. 2):

$$
U_{B}=S_{B} A
$$

where $U_{\mathrm{B}}$ (yuan $\mathrm{yr}^{-1}$ ) is the total conservation value of species diversity for all the stands, $S_{\mathrm{B}}$ (yuan $\mathrm{hm}^{-2} \mathrm{yr}^{-1}$ ) is the conservation value of species diversity per unit area, and $A\left(\mathrm{hm}^{-2}\right)$ is the stand area.

\section{Inclusion of the endangered species} index in the Shannon-Wiener index In this study, endangered species were divided into four categories, according to the "China Species Red List" (Wang \& Xie 2004)": (i) critically endangered; (ii) endangered; (iii) vulnerable; and (iv) near threatened (Tab. 2). An endangered species index was used to modify eqn. 2 as follows (eqn. 3):

$$
U_{B}=\left(1+\sum_{i=1}^{n} E_{i} \cdot 0.1\right) S_{B} A
$$


where $E_{\mathrm{i}}$ is the endangered index of the $i$ th endangered species in a specific assessed stand $\left(E_{\mathrm{i}}=1,2,3,4\right.$ - see Tab. 2), and $n$ is the number of endangered species.

Inclusion of the endemic species index in the Shannon-Wiener index

Since endemic species are not considered in the estimation of the biodiversity conservation value (see eqn. 3 ), an endemic species index was defined and included into eqn. 3. The final formula was as follows (eqn. 4):

$$
U_{B}=\left(1+\sum_{i=1}^{n} E_{i} \cdot 0.1+\sum_{x=1}^{m} B_{x} \cdot 0.1\right) S_{B} A
$$

where $B_{\mathrm{x}}$ is the endemic index of the $x$-th endemic species in a specific assessed stand $\left(B_{\mathrm{x}}=0,1,2,3,4-\right.$ see Tab. 3$), m$ is the total number of endemic species, and $n$ is the total number of endangered species.

\section{Data resources}

Floristic and inventory data of the two provinces were taken from the $7^{\text {th }}$ Chinese forest resource inventory. All the stand types considered in both Yunnan and Jilin provinces are shown in Tab. 4.

\section{Results}

Conservation values by the standard Shannon-Wiener index

The total conservation values of different stand types in Yunnan and Jilin provinces
Tab. 2 - The endangered species index and endangered species categories.

\begin{tabular}{cll}
\hline $\begin{array}{l}\text { Endangered } \\
\text { species index }\end{array}$ & $\begin{array}{l}\text { Endangered } \\
\text { categories }\end{array}$ & $\begin{array}{l}\text { Endangered } \\
\text { species }\end{array}$ \\
\hline 4 & critically endangered & \\
\hline 3 & endangered & $\begin{array}{l}\text { See the "China Species Red List" } \\
(2004)\end{array}$ \\
\hline 2 & vulnerable & \\
\hline 1 & near threatened & \\
\hline
\end{tabular}

Tab. 3 - The endemic species index according to their geographic distribution.

\begin{tabular}{cl}
\hline $\begin{array}{l}\text { Endemic } \\
\text { species index }\end{array}$ & Species distribution \\
\hline 4 & $\begin{array}{l}\text { Species exhibits a small-scale distribution in the mountains or in a } \\
\text { special natural and geographical environment }\end{array}$ \\
\hline 3 & $\begin{array}{l}\text { Species is distributed in a larger natural and geographical environment, } \\
\text { e.g., larger islands, plateaus, and numerous mountains }\end{array}$ \\
\hline 2 & $\begin{array}{l}\text { Species is distributed in a specific continent } \\
1\end{array}$ \\
\hline 0 & Species is distributed in at least two continents \\
\hline
\end{tabular}

were 268.65 and 123.94 billion yuan $\mathrm{yr}^{-1}$, broadleaved and coniferous mixed forest, respectively (Fig. 1a, Fig. 2a). The top 10 coniferous mixed forest, Pinus sylvestris conservation values in the Yunnan pro- forest, Populus forest, shrubbery forest, vince were as follows: other soft broad- miscellaneous tree forest, and Pinus koraleaved forest, broadleaved mixed forest, iensis forest. shrubbery forest, broadleaved and coniferous mixed forest, other hardwood, Quer- Inclusion of the endangered species cus forest, Pinus yunnanensis forest, coni- index ferous mixed forest, economic forest, and The endangered species index $\left(E_{\mathrm{i}}\right)$ desCodonopsis lanceolata forest. In the Jilin cribed above was used to amend the Shanprovince, the top ten were: broadleaved non-Wiener index. Using the modified inmixed forest, Quercus forest, Larix forest, dex (eqn. 3), the total conservation values

Tab. 4 - The stand types considered in this analysis for the Yunnan and Jilin provinces (China).

\begin{tabular}{|c|c|c|c|c|c|}
\hline \multicolumn{3}{|c|}{ Yunnan province } & \multicolumn{3}{|c|}{ ilin province } \\
\hline Num & Stand type & $\begin{array}{l}\text { Area } \\
\left(10^{4} \mathrm{ha}\right)\end{array}$ & Num & Stand type & $\begin{array}{l}\text { Area } \\
\left(10^{4} \mathrm{ha}\right)\end{array}$ \\
\hline 1 & Other soft broadleaved forest & 162.20 & 1 & Miscellaneous tree forest & 407.71 \\
\hline 2 & Broadleaved mixed forest & 239.46 & 2 & Broadleaved mixed forest & 109.92 \\
\hline 3 & Shrubbery forest & 102.01 & 3 & Shrubbery forest & 79.37 \\
\hline 4 & Broadleaved and coniferous mixed forest & 145.39 & 4 & Broadleaved and coniferous mixed forest & 86.48 \\
\hline 5 & Other hardwood forest & 79.64 & 5 & Coniferous mixed forest & 29.53 \\
\hline 7 & Economic forest & 310.47 & 7 & Quercus spp. forest & 65.72 \\
\hline 8 & Bamboo forest & 50.39 & 8 & Larix spp. forest & 18.98 \\
\hline 9 & Other Taxodium forest & 19.24 & 9 & Populus spp. forest & 8.18 \\
\hline 10 & Cunninghamia lanceolata forest & 35.50 & 10 & Pinus koraiensis forest & 8.07 \\
\hline 11 & Abies alba forest & 34.06 & 11 & Picea asperata forest & 3.98 \\
\hline 12 & Pinus armandii forest & 32.14 & 12 & Betula platyphylla forest & 5.67 \\
\hline 13 & Pinus kesiya forest & 59.03 & 13 & Ulmus pumila forest & 4.79 \\
\hline 15 & Eucalyptus robusta forest & 24.00 & 15 & Juglans mandshurica forest & 1.90 \\
\hline 16 & Keteleeria fortunei forest & 23.52 & 16 & Fraxinus mandshurica forest & 0.75 \\
\hline 17 & Tsuga chinensis forest & 3.36 & 17 & Salix babylonica forest & 0.41 \\
\hline 18 & Schima superb forest & 6.72 & 18 & Betula costata forest & 0.53 \\
\hline 19 & Picea asperata forest & 6.24 & 19 & Abies nephrolepis forest & 0.16 \\
\hline 20 & Quercus spp. forest & 12.51 & 20 & Tilia amurensis forest & 0.15 \\
\hline 21 & Betula spp. forest & 3.84 & 21 & Phellodendron amurense forest & 0.03 \\
\hline 22 & Pinus yunnanensis forest & 3.36 & 22 & Acer mono forest & 0.05 \\
\hline 23 & Populus spp. forest & 3.36 & 23 & Other pine forest & 0.01 \\
\hline 24 & Cupressus funebris forest & 2.88 & 24 & & - \\
\hline 25 & Larix spp. forest & 1.44 & 25 & & - \\
\hline 26 & Cinnamomum forest & 0.48 & 26 & & - \\
\hline 27 & Paulownia fortunei forest & 0.48 & 27 & & - \\
\hline 28 & Cryptomeria fortunei forest & 0.48 & 28 & & - \\
\hline
\end{tabular}




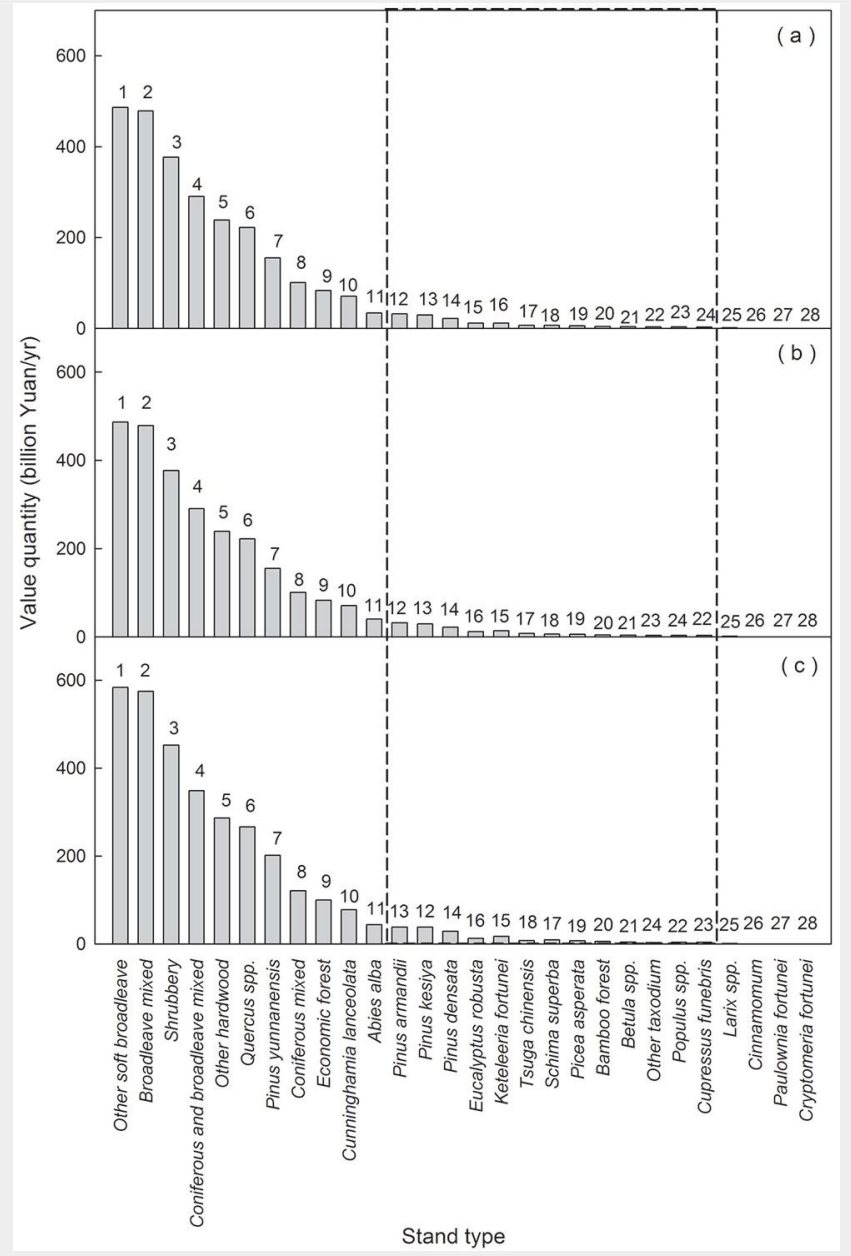

Fig. 1 - Conservation values of different forest stand types in the Yunnan province based on: (a) the standard Shannon-Wiener index (eqn. 2); (b) the inclusion of the endangered species index (eqn. 3); and (c) the inclusion of both the endangered species index and the endemic species index (eqn. 4). The numbers on the top of each bar are the ranking of each stand type based on the calculated conservation value. The rectangle within the dotted lines represents the stands whose conservation value ranking changed using the different indexes.

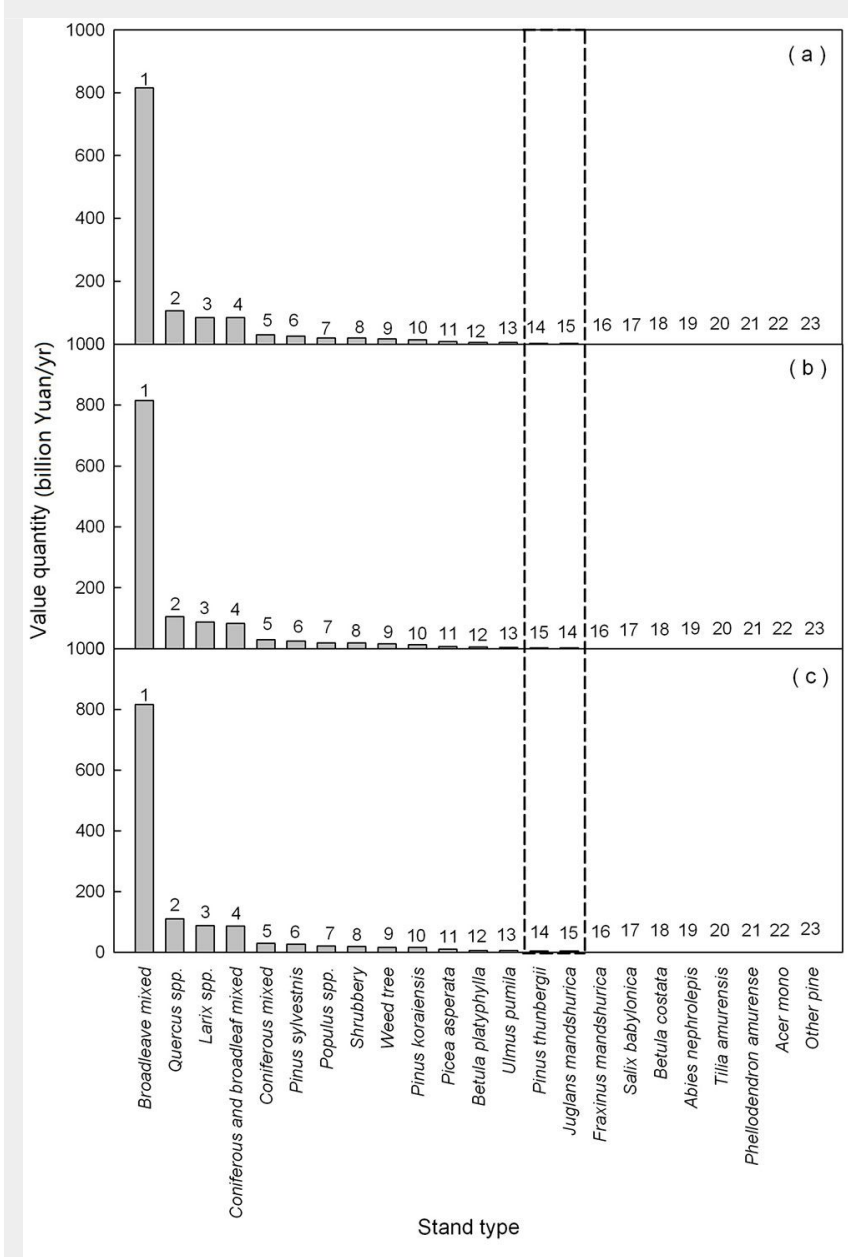

Fig. 2 - Conservation values of different forest stand types in the Jilin province based on: (a) the standard Shannon-Wiener index (eqn. 2); (b) the inclusion of the endangered species index (eqn. 3); and (c) the inclusion of both the endangered species index and the endemic species index (eqn. 4). The numbers on the top of each bar are the ranking of each stand type based on the calculated conservation value. The rectangle within the dotted line represents the stands whose conservation value ranking changed using the different indexes. of the different stand types in the Yunnan and Jilin provinces were 269.77 and 124.60 billion yuan $\mathrm{yr}^{-1}$, respectively (Fig. 1b, Fig. $2 b)$. The top 10 conservation values in the Yunnan and Jilin provinces did not change. In the Yunnan province, the conservation value of the Keteleeria fortunei forest moved up one place, replacing the originally $15^{\text {th }}$ ranked Eucalyptus robusta forest. The conservation value of the Cupressus funebris forest moved up two places and ranked $22^{\text {th }}$. In the Jilin province, the conservation value of the Juglans mandshurica forest moved up one place and ranked $14^{\text {th }}$.

Inclusion of the endemic species index The endemic species index $\left(B_{\mathrm{x}}\right)$ was used to modify the Shannon-Wiener index. Using eqn. 4, the total conservation values of different stand types in the Yunnan and Jilin provinces were 324.44 and 125.74 billion yuan $\mathrm{yr}^{-1}$, respectively (Fig. 1C, Fig. $2 \mathrm{C}$ ). The top 10 conservation values in the Yun- nan and Jilin provinces did not change. In the Yunnan province, the conservation value of the Pinus kesiya forest moved up one place and replaced the originally $12^{\text {th }}$ ranked Pinus armandii forest. The Shorea superba forest also moved up one place. The conservation value of the Populus forest moved up two places and ranked $22^{\text {th }}$. In Jilin province, the conservation value of the J. mandshurica forest moved down one place and ranked $15^{\text {th }}$.

\section{Discussion}

In this study, the total conservation values of different forest ecosystems increased in both Yunnan and Jilin provinces when endangered and endemic species were included by suitable indexes into the Shannon-Wiener index. The Yunnan province is located in a tropical belt of China and is renowned for its species richness, especially for endangered and endemic species (Ge et al. 1997). Contrastingly, the
Jilin province is in the northern of China, thus the overall number of species is lower than that found in the Yunnan province. In both cases, the conservation values increased dramatically when the endangered and endemic species indexes were included in the assessment.

In the Yunnan province, as the endangered species index of $K$. fortunei is 2 and E. robusta is not included in the "Chinese Species Red List", the conservation value of $K$. fortune surpassed that of E. robusta when considering the endangered species index in the assessment. The rank of the $C$. funebris conservation value increased from 24 to 22 as its endangered index is 2; thus, the conservation value of $C$. funebris surpassed those of the Populus and other Taxodium forests when including the endangered species index.

When the endemic species index was included the Shannon-Wiener index (eqn. 4), the total conservation value increased 
dramatically. The conservation value of the $P$. kesiya forest increased from 2.21 to 2.87 billion yuan $\mathrm{yr}^{-1}$, and replaced the originally $12^{\text {th }}$ ranked $P$. armandii forest. This is because the endemic index of $P$. kesiya is 3 , and it is only distributed in the Yunnan province. As an indigenous species, the conservation value of $S$. superba also increased from 0.67 to 0.94 billion yuan $\mathrm{yr}^{-1}$, replacing the Tsuga chinensis forest in the ranking. The conservation value of the Populus forest increased from 0.34 to 0.40 billion yuan $\mathrm{yr}^{-1}$, and moved up two places in the ranking, as an indigenous species, Populus yunnanensis, grows only in the Yunnan province.

In the Jilin province, when the endangered species index was included in the assessment, the F. mandshurica forest replaced the Pinus thunbergii forest type by moving from $16^{\text {th }}$ to $15^{\text {th }}$ place in the ranking, because it is classified as a vulnerable species. However, when the endemic species index was included in the assessment, the conservation value of $F$. mandshurica moved down one place, ranking $16^{\text {th }}$ again. Although the endemic indexes of both $F$. mandshurica and $P$. thunbergii were 2 , the areas covered by these two species are very different, changing the ranking based on conservation values.

In this study, the economic value of biodiversity was described by the species diversity conservation value, and the assessments carried out using two different modified forms of the Shannon-Wiener index. Compared with the conservation values based on the standard Shannon-Wiener index, increased values were obtained when endangered and endemic species indexes were incorporated in the assessment. The conservation values of endangered and endemic species can therefore contribute to the protection of endangered and endemic species in these two provinces of China.

Ancient trees are worthy of great conservation efforts because they are a record of a region's climate, hydrology, geology, geography, vegetation, ecology, and other natural conditions, and have been witness to human activity and the historical process of social development. Additionally, ancient trees have special significance for the study of tree physiology because they allow researchers to analyze how a tree's physiological processes change as it ages. Additionally, ancient trees are also the foundation of forest ecosystems, and an ancient tree index should also be considered when calculating biodiversity conservation values. Since data on ancient trees were not available, the conservation values of ancient trees were not evaluated in this assessment. However, this will be the future direction of our research.

\section{Acknowledgements}

This work was financially supported by the Special Fund for Forestry Scientific Research in the Public Interest No.
201404303, No. 20130430101, No. 201204101 and the National Basic Research and Development Program of China (973 Program) Grant No. 2011CB403201, and it was subsidized by CFERN \& GENE Award Funds on Ecological Paper. Funding agencies were involved in the data collection and analysis, and participated in the consultation regarding the decision to publish this paper.

\section{References}

Bollmann K, Bergamini A, Senn-Irlet B, Nobis M, Duelli P, Scheidegger C (2009). Concepts, instruments and challenges for the conservation of biodiversity in the forest. Schweizerische Zeitschrift fur Forstwesen 160 (3): 6753. - doi: 10.3188/szf.2009.0053

Bonn A, Rodrigues AS, Gaston KJ (2002). Threatened and endemic species: are they good indicators of patterns of biodiversity on a national scale? Ecology Letters 5 (6): 733-741. - doi: 10.1046/j.1461-0248.2002.00376.x

Brooks TM, Mittermeier RA, Da Fonseca GAB, Gerlach J, Hoffmann M, Lamoreux JF, Mittermeier CG, Pilgrim JD, Rodrigues ASL (2006). Global biodiversity conservation priorities. Science 313: 58-61. - doi: 10.1126/science.1127609

Cardinale BJ, Srivastava DS, Duffy JE, Wright JP, Downing AL, Sankaran M (2006). Effects of biodiversity on the functioning of trophic groups and ecosystems. Nature 443: 989-992. - doi: 10.1038/nature05202

Ceballos G, Rodriguez P, Medellin RA (1998). Assessing conservation priorities in megadiverse Mexico: mammalian diversity, endemicity, and endangerment. Ecological Applications 8 (1): 8-17. - doi: 10.1890/1051-0761(1998)008[000 8:ACPIMM]2.0.CO;2

Cheng KW, Zang RG (2004). Advances in species endangerment assessment. Chinese Biodiversity 12 (5): 534-540.

Christie M, Hanley N, Warren J, Murphy K, Wright R, Hyde T (2006). Valuing the diversity of biodiversity. Ecological Economics 58 (2): 304-317. - doi: 10.1016/j.ecolecon.2005.07.034

Cushman SA, McKelvey KS, Flather CH, McGarigal $K$ (2008). Do forest community types provide a sufficient basis to evaluate biological diversity? Frontiers in Ecology and the Environment 6 (1): 13-17. - doi: 10.1890/070039

Dobson AP, Rodriguez JP, Roberts WM, Wilcove DS (1997). Geographic distribution of endangered species in the United States. Science 275: 550-553. - doi: 10.1126/science.275.5299.550

PRC Forestry Industry Standard (2008). Specifications for assessment of forest ecosystem services in China. LY/T 1721-2008, Forestry industry standard of the People's Republic of China, Standards Press of China, Beijing, China, pp. 35.

Fu LG (1991). China plant red data book - rare and endangered plants: volume I. Science Press of China, Beijing, China, pp. 1992. [online] URL: http://www.cabdirect.org/abstracts/199403007 03.html

Ge S, Zhang DM, Wang HQ, Rao GY (1997). Allozyme variation in Ophiopogon xylorrhizus, an extreme endemic species of Yunnan, China. Conservation Biology 11 (2): 562-565. - doi: 10.1046/j.1523-1739.1997.96011.x

Jakobsson KM, Dragun A (2001). The worth of a possum: valuing species with the contingent valuation method. Environmental and Resource Economics 19 (3): 211-227. - doi: 10.1023/A:1011 128620388

Kellert SR (1997). The value of life: biological diversity and human society. Island Press, Washington, DC, USA, pp. 283. [online] URL: http://books.google.com/books?id=CAq8BwAA QBAJ

Kuuluvainen T (2002). Natural variability of forests as a reference for restoring and managing biological diversity in boreal Fennoscandia. Silva Fennica 36 (1): 97-125. [online] URL: http:// m.metla.eu/silvafennica/full/sf36/sf361097.pdf

Li SN (2007). Study on forest ecosystem services in Jiangxi province and Dagangshan. Chinese Academy of Forestry, Beijing, China. pp. 25-26. [in Chinese]

Ma CL, Moseley RK, Chen WY, Zhou ZK (2007). Plant diversity and priority conservation areas of Northwestern Yunnan, China. Biodiversity and Conservation 16 (3): 757-774. - doi: 10.1007/ s10531-005-6199-6

Mooney HA (2009). The ecosystem-service chain and the biological diversity crisis. Philosophical Transactions of the Royal Society B: Biological Sciences 365 (1537): 31-39. - doi: 10.1098/rstb.20 09.0223

Naeem S, Thompson LJ, Lawler SP, Lawton JH, WoodfIn RM (1994). Declining biodiversity can alter the performance of ecosystem. Nature 368: 734-737. - doi: 10.1038/368734ao

Niu X, Wang B, Liu SR, Liu CJ, Wei WJ, Kauppi PE (2012). Economical assessment of forest ecosystem services in China: characteristics and implications. Ecological Complexity 11: 1-11. - doi: 10.1016/j.ecocom.2012.01.001

Niu X, Wang B, Wei WJ (2013). Chinese forest ecosystem research network: a platform for observing and studying sustainable forestry. Journal of Food, Agriculture and Environment 11 (2): 1008-1016. [online] URL: http://worldfood.net/download/journals/2013-issue_2/2013issue_2-environment/e42.pdf

Norris K (2012). Biodiversity in the context of ecosystem services: the applied need for systems approaches. Philosophical Transactions of the Royal Society B: Biological Sciences 367 (1586): 191-199. - doi: 10.1098/rstb.2011.0176

Nunes PA, Van Den Bergh JC (2001). Economic valuation of biodiversity: sense or nonsense? Ecological Economics 39 (2): 203-222. - doi: 10.1016/So921-8009(01)00233-6

Odum HT (1950). Bird populations of the highlands plateau in relation to plant succession and avian invasion. Ecology 31: 587-605. - doi: $10.2307 / 1931577$

OECD (1996). Saving biological diversity-economic incentives. OECD, Paris, France, pp. 2-5.

Pimentel D, Wilson C, Mccullum C, Huang R, Dwen P, Flack J, Tran Q, Saltman T, Cliff B (1997). Economic and environmental benefits of biodiversity. BioScience 47 (11): 747-757. doi: 10.2307/1313097

Purvis A, Hector A (2000). Getting the measure of biodiversity. Nature 405: 212-219. - doi: 10.103 8/35012221

Schwartz MW, Brigham CA, Hoeksema JD, Lyons KG, MIlls MH, Van Mantgern PJ (2000). Linking biodiversity to ecosystem function: implications for conservation ecology. Oecologia 122: 
297-305. - doi: 10.1007/s004420050035 Simberloff D (1999). The role of science in the preservation of forest biodiversity. Forest Ecology and Management 115 (2-3): 101-111. - doi: 10.1016/S0378-1127(98)00391-0

Sodhi NS, Koh LP, Brook BW, Ng PK (2004). Southeast Asian biodiversity: an impending disaster. Trends in Ecology and Evolution 19 (12): 654-660. - doi: 10.1016/j.tree.2004.09.006

Song $L$ (2004). Research on the assessment of forest biodiversity in Mt. Tai. Shandong Agricultural University, Tai An, China, pp. 17.

Terborgh JW (1998). The big things that run the world: a sequel to $\mathrm{E}$. O. Wilson. Conservation Biology 2 (4): 402-403. - doi: 10.1111/j.1523-1739. 1988.tboo207.x

Tilman D, Lehman CL, Bristow CE (1996). Productivity and sustainability influenced by biodiversity in grassland ecosystems. Nature 379 (6567): 718-720. - doi: 10.1038/379718ao

United Nations (1993). Report of the United Nations conference on environment and develop- ment. United Nations Publications, New York, USA, pp. 2.

Van Jaarsveld AS, Freitag S, Chown SL, Muller C, Koch S, Hull H, Bellamy C, Kruger M, EndrodyYounga S, Mansell MW, Scholtz CH (1998). Biodiversity assessment and conservation strategies. Science 279: 2106-2108. - doi: 10.1126/scien ce.279.5359.2106

Vilenkin BY, Chikatunov VI, Coad BW, Schileyko $A A$ (2009). A random process may control the number of endemic species. Biologia 64 (1): 107-112. - doi: 10.2478/s11756-009-0020-z

Wang B, Lu SW (2009). Evaluation of economic forest ecosystem services in China. Chinese Journal of Applied Ecology 20 (2): 417-425. [online] URL: http://europepmc.org/abstract/ med/19459385

Wang S (1998). China red data book of endangered animals. Science Press of China, Beijing, China, pp. 3-5.

Wang B, Zheng QH, Guo H (2008). Economic value assessment of forest species diversity conservation in China based on the ShannonWiener index. Forest Research - Chinese Edition 21 (2): 268-274. [online] URL: http://en. cnki.com.cn/Article_en/CJFDTOTAL-LYKX20080 2027.htm

Wang B, Ren XX, Hu W (2011a). Assessment of forest ecosystem services value in China. Scientia Silvae Sinicae 47 (2): 145-153.

Wang B, Wei JS, Hu W (2011b). The assessment of forest ecosystem services evaluation for shrubbery-economic forest-bamboo forest in China. Acta Ecologica Sinica 31 (7): 1936-1945.

Wang S, Xie Y (2014). China species red list: I. Higher Education Press, Beijing, China, pp. 3598.

Yue TX, Haber W, Grossmann WD, Kasperidus HD (1998a). Discussion on models for species diversity and suggestion on a comprehensive model. Ecological Modelling 9: 1-15.

Yue TX, Haber W, Grossmann WD, Kasperidus HD (1998b). Towards the satisfying model for biological diversity. Ekologia 17 (3): 129-141. 